\title{
Abundance and population structure of Plesionika narval (Fabricius, 1787) in the Northeastern Atlantic
}

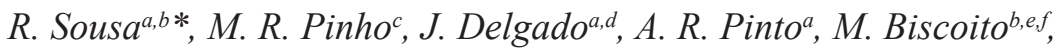 \\ T. Dellingerg ${ }^{g}$ and P. Henriques ${ }^{h}$
}

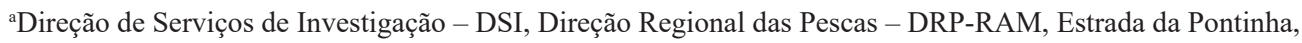
CP 9004-562, Funchal, Madeira, Portugal

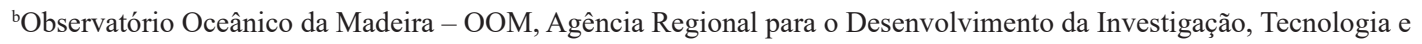
Inovação - ARDITI, Edifício Madeira Tecnopolo, Piso 0, CP 9020-105, Funchal, Madeira, Portugal

'Departamento de Oceanografia e Pescas - DOP, Universidade dos Açores - UAc, Cais de Santa Cruz, CP 9901-862, Horta, Portugal

dCentro Interdisciplinar de Investigação Marinha e Ambiental - CIIMAR, Rua dos Bragas 289, CP 4500-123, Porto, Portugal

'Museu de História Natural do Funchal - MMF, Rua da Mouraria, 31, CP 9000-047, Funchal, Madeira, Portugal

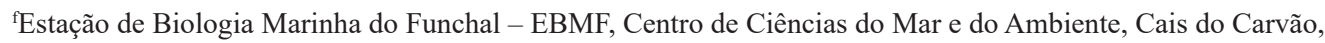
CP 9000-107, Funchal, Madeira, Portugal

gLaboratório Biologia Marinha e Oceanografia, Universidade da Madeira - UMa, Estação Biologia Marinha do Funchal, Cais do Carvão, Prom. Orla Marítima, CP 9000-107, Funchal, Portugal

hUniversidade da Madeira - UMa, Campus da Penteada, CP 9000-390, Funchal, Portugal

*e-mail: ricardo.sousa@oom.arditi.pt

Received: May 6, 2017 - Accepted: August 9, 2017 - Distributed: February 28, 2019

(With 4 figures)

\begin{abstract}
Analysis of abundance and population structure of Plesionika narval was performed on data concerning 5,255 specimens obtained from 62 fishing sets carried out off the Madeira archipelago (Northeastern Atlantic) between 2004 and 2008 in a depth range from 101 to $350 \mathrm{~m}$. Abundance ranged from 0.01 to 19.74 specimens-per-trap and significant differences were found between seasons, probably as a result of an increment of population in the spring during the recruitment season. The analysis of size distribution revealed that the carapace length (CL) ranged from 2.45 to $28.61 \mathrm{~mm}$ and that mean female size consistently exceeded that of males. Differences in mean CL were statistically significant between depth strata and seasons. Of the specimens sampled, $57.00 \%$ were males, $41.88 \%$ females and $1.42 \%$ undetermined. Sex ratio also differed significantly between seasons according to depth strata, consolidating the hypothesis of the existence of seasonal migrations related with the reproductive cycle of this species. Ovigerous females showed larger sizes and occurred all year around and remain in shallow waters in winter, summer and autumn and move to deeper waters in spring. The highest frequency of ovigerous females was recorded in summer, between 151 and $200 \mathrm{~m}$ deep supporting the hypothesis that spawning of this species occurs in shallow waters, especially in late summer.
\end{abstract}

Keywords: Plesionika narval, pandalids, population structure, size composition, Madeira.

\section{Abundância e estrutura populacional de Plesionika narval (Fabricius, 1787) no Atlântico Nordeste}

\section{Resumo}

O estudo de abundância e dinâmica populacional de Plesionika narval foi efetuado com 5.255 espécimes provenientes de 62 lances de pesca realizados ao largo do arquipélago da Madeira (Atlântico Nordeste) de 2004 a 2008 entre 101 e 350 m de profundidade. A abundância oscilou entre 0,01 e 19,74 espécimes-por-armadilha com diferenças significativas entre estações provavelmente devido ao aumento da população na primavera durante o período de recrutamento. A análise da distribuição de tamanhos revelou que o comprimento da carapaça (CL) variou entre 2,45 e 28,61 mm e que o tamanho médio das fêmeas excedeu o dos machos. Verificaram-se diferenças significativas no CL médio entre estrato de profundidade e estação. Do total amostrado, $57,00 \%$ foram machos, $41,88 \%$ fêmeas e 1,42\% indeterminados. A razão de sexos também diferiu significativamente entre estações de acordo com a profundidade, consolidando a hipótese da existência de migrações sazonais relacionadas com o ciclo reprodutivo desta espécie. As fêmeas ovadas 
apresentaram maiores tamanhos e ocorreram durante todo o ano permanecendo em águas pouco profundas no inverno, verão e outono e migrando para águas profundas na primavera. A maior frequência de fêmeas ovadas foi registada no verão, entre 151 e $200 \mathrm{~m}$ de profundidade reforçando a hipótese de que a desova desta espécie ocorre em águas menos profundas, especialmente no final do verão.

Palavras-chave: Plesionika narval, pandalídeos, estrutura populacional, composição tamanhos, Madeira.

\section{Introduction}

Plesionika narval (Fabricius, 1787) is acknowledged by FAO as a species of interest to fisheries (Holthuis, 1980). This species usually occurs in great abundance and is easily captured in bottom trawls and traps (Lagardère, 1981; Holthuis, 1987; Biscoito, 1993). P. narval is exploited in a small scale artisanal fishery in Madeira (Biscoito, 1993), the Canary Islands (González et al., 1997) and the Mediterranean Sea (Arculeo et al., 2002). This species occurs from the surface down to $910 \mathrm{~m}$ of depth in a large variety of habitats including muddy, sand-muddy, rocky bottoms and submarine caves (Holthuis, 1987; Thessalou-Legaki, 1989; Biscoito, 1993). It is a cosmopolitan species that can be found in the Eastern Atlantic Ocean, from the southwest Iberian Peninsula to Angola, the Mediterranean Sea, the Red Sea and Indo-West Pacific from Madagascar to French Polynesia (Crosnier and Forest, 1973; Holthuis, 1980; Chan and Crosnier, 1991; Martins and Hargreaves, 1991; González et al., 1997; Li, 2006; Li and Davie, 2006).

Pandalid shrimps play an important role within benthic assemblages due to their abundance and trophic relationships (Cartes et al., 1993), representing a significant portion of demersal fish and cephalopods diets (Cartes et al., 2002). As such, to guarantee the sustainable exploitation of $P$. narval, studies on the population structure of this species are of vital importance. The population structure is inferred from the distribution / size composition, sex ratio and bathymetric distribution of a population. Awareness on the life cycle strategies of a population, the vertical distribution and sexual segregation appear to be fundamental in establishing regulatory measures to the management of stocks and in the selection of appropriate fishing strategies for each target species (Thessalou-Legaki, 1989; Carbonell and Abelló, 1998).

This work aims to study the abundance and population structure of $P$. narval comprising size composition, sex ratio and proportion of females according to their ovigerous condition in relation to the bathymetric range and season. The analysis will comprise samples obtained in experimental fishing surveys carried out off the Madeira archipelago and will provide additional information about this ecologically important species and contribute to the its proper management and conservation.

\section{Material and Methods}

\subsection{Sampling}

The material examined in this study was obtained using a random stratified sampling design, considering two variables: depth strata (100-150 m, 151-200 m, 201-250 m, 251-300 m, 301-350 m) and season (winter, spring, summer and autumn).
A total of 62 fishing sets were carried out on the insular shelves and slopes off the archipelago of Madeira, Eastern Central Atlantic $\left(32^{\circ} 00^{\prime}-33^{\circ} 30^{\prime} \mathrm{N} ; 1^{\circ} 30^{\prime}-18^{\circ} 00^{\prime} \mathrm{W}\right)$ in research surveys using bottom floating traps according to Sousa et al. (2017), over a period of 4 years, from 2004 to 2008.

\subsection{Data collection}

Data such as geographic position, depth, number of traps used, deployment and hauling time was registered for each of the 62 fishing sets. After hauling, the traps were separated according to their condition as valid (without damaged and correctly closed) or invalid traps (damage or opened). The content of the invalid traps was not used for the purposes of abundance estimates and the content of the valid traps was separated by species, weighted, and counted.

All specimens were sampled. Carapace length (CL) was measured to the nearest $0.01 \mathrm{~mm}$, using electronic digital calipers, from the posterior margin of the orbit to the posterior dorsal margin of the carapace. Sex determination was performed through the observation, under a stereoscopic microscope, of masculine appendages in the second pair of pleopods (Zariquiey-Alvarez, 1968; Thessalou-Legaki, 1989). Ovigerous condition was determined for females by the presence or absence of external eggs.

\subsection{Data analysis}

The population structure analysis focused on the abundance, size composition, sex ratio and proportion of ovigerous and nonovigerous females, in relation to depth and season.

Statistical analysis was performed using general linear models (GLM) when the response variable has a Gaussian distribution or generalized linear models (GzLM) when the response variable has a different type of distribution, to test the significance of the explanatory variables (Crawley, 2002). All statistical analysis was performed using IBM SPSS Statistics 20.0 (IBM, 2011).

\subsubsection{Abundance and distribution}

The abundance was estimated using the catch per unit of effort in number (CPUEN), corresponding to the ratio between the total number of captured specimens and the fishing effort by fishing set. Differences in the mean abundance, between depth strata and season, were analyzed by applying the statistical Kruskal-Wallis test $(\mathrm{p}<0.05)$ (Zar, 1996). The influence of the explanatory variables, depth strata and seasons on the response variable abundance was evaluated using GzLM analysis. 


\subsubsection{Size composition}

Differences in mean size per sex, ovigerous condition, depth strata and season were tested applying Brown-Forsythe test statistics $(\mathrm{p}<0.05)(\mathrm{Zar}, 1996)$. The evaluation of the influence of the explanatory variables sex, depth stratum and season on the response variable $\mathrm{CL}$ was performed using GLM analysis.

\subsubsection{Sex ratio and proportion of ovigerous females}

The sex ratio was estimated as the relative proportion of males and females over the total number of individuals by depth stratum and season, and the proportion of ovigerous and nonovigerous females was estimated as the ratio between the number of ovigerous or nonovigerous females and the total number of females by CL class, depth strata and season. Chi-square test $(p<0.05)$ was used to check for differences between the proportion of males and females and between the proportion of ovigerous and nonovigerous females. Kruskal-Wallis test $(\mathrm{p}<0.05)$ was used to determine differences in the sex ratio and proportion of females according to depth strata and season (Zar, 1996).

The evaluation of the influence of the explanatory variables depth stratum and the season on the response variables sex and ovigerous condition was performed using GzLM.

\section{Results}

A total of 5,255 specimens were sampled between 101 and $350 \mathrm{~m}$ deep, including 3,032 males, 2,201 females and 22 with unspecified sex. With regard to females 1,639 were ovigerous and 562 were nonovigerous.

\subsection{Abundance and distribution}

Abundance of P. narval ranged from 0.01 to 19.47 specimens per trap, with a mean abundance of 1.42 specimens per trap (see Figure 1). The highest mean abundance was found between 151 and $200 \mathrm{~m}(\bar{x}=2.19 ; \mathrm{SE}=1.09 ; \mathrm{n}=1,462)$ and the lowest between 301 and $350 \mathrm{~m}(\bar{x}=0.09 ; \mathrm{SE}=0.06, \mathrm{n}=237)$. The differences in the mean abundance between strata were not statistically significant $(\chi 2=3.76 ; \mathrm{p}>0.05)$. In relation to the season the highest abundance occurred in the summer $(\bar{x}=5.55 ; \mathrm{SE}=3.57 ; \mathrm{n}=347)$ and the lowest in the winter $(\bar{x}=0.63 ; \mathrm{SE}=0.45 ; \mathrm{n}=285)$. The differences in mean abundance between seasons were statistically significant $\left(\chi^{2}=8.00, \mathrm{p}<0.05\right)$.
The mean abundance per depth stratum and season showed higher values in the 151-200 $\mathrm{m}$ depth stratum in summer $(\bar{x}=11.19 ; \mathrm{SE}=8.28, \mathrm{n}=137)$ and in the $201-250 \mathrm{~m}$ depth stratum in autumn $(\bar{x}=1.73 ; \mathrm{SE}=1.03 ; \mathrm{n}=1,010)$, nonetheless the mean abundance per depth strata between seasons was not significantly different $\left(\chi^{2}=0.21, p>0.05\right)$.

\subsection{Size composition}

The mean CL was $16.56 \mathrm{~mm}$ for combined sexes, $15.22 \mathrm{~mm}$ for males and $18.24 \mathrm{~mm}$ for females (as shown in Table 1). Males ranged from 2.45 to $27.22 \mathrm{~mm}$ and females ranged between 6.72 and $28.61 \mathrm{~mm}$.

Males are generally more abundant in the lower CL classes and females in the higher classes (see Figure 2A). Approximately $60 \%$ of the sampled males were distributed between 2.00 and $16.00 \mathrm{~mm}$, contrary to females that had $89 \%$ of the specimens ranging between 16.00 and $29.00 \mathrm{~mm}$ of CL. There was a statistically significant difference between size class distribution per $\operatorname{sex}(\mathrm{F}=2,011.46 ; \mathrm{p}<0.05)$.

Nonovigerous females were distributed between 7.75 and $22.85 \mathrm{~mm}$ and the ovigerous females between

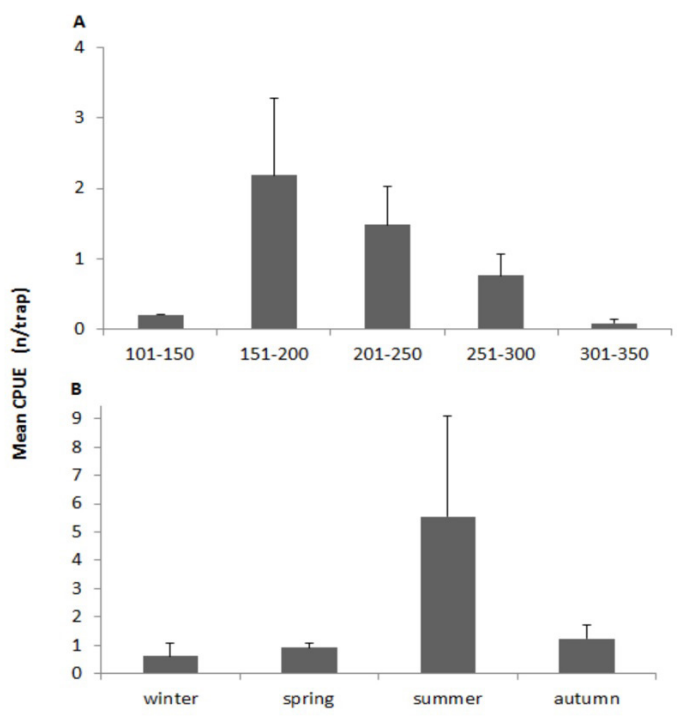

Figure 1. Mean abundance and standard error of Plesionika narval caught in Madeira archipelago, Northeastern Atlantic, between 2004 and 2008 per depth stratum (A) and season (B).

Table 1. Descriptive statistics per sex and ovigerous condition.

\begin{tabular}{cccccc}
\hline Sex & $\mathbf{N}$ & $\mathbf{C L}$ min. $(\mathbf{m m})$ & $\mathbf{C L}$ max. $(\mathbf{m m})$ & $\overline{\mathbf{C L}}(\mathbf{m m})$ & $\mathbf{S E}$ \\
\hline Combined sexes & 5,255 & 2.45 & 28.61 & 16.56 & 0.04 \\
Males & 3,032 & 2.45 & 27.22 & 15.22 & 0.05 \\
Females & 2,201 & 6.72 & 28.61 & 18.24 & 0.04 \\
Nonovigerous females & 562 & 7.75 & 22.85 & 17.11 & 0.05 \\
Ovigerous females & 1,639 & 6.72 & 28.61 & 18.63 & 0.05 \\
\hline
\end{tabular}

N, sample size; CL min., minimum size; CL max., maximum size; $\overline{\mathbf{C L}}$, mean size; SE, standard error. 

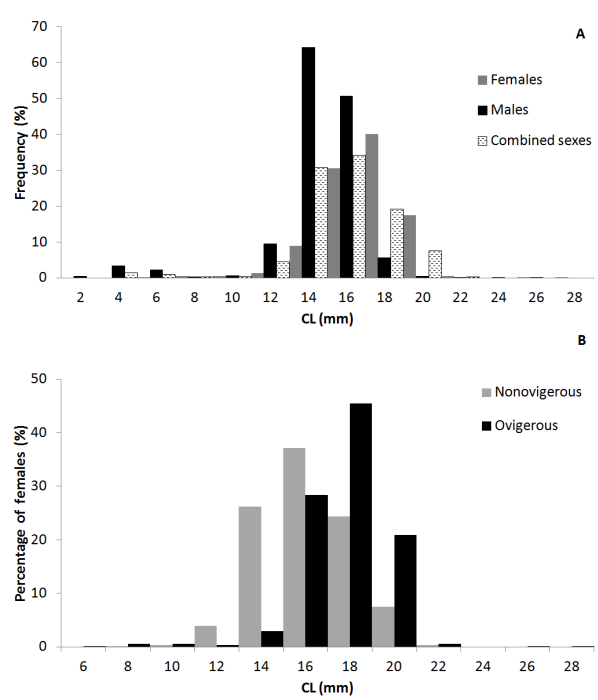

Figure 2. Size frequency of Plesionika narval caught in Madeira archipelago, Northeastern Atlantic, between 2004 and 2008 per size class for combined sexes, males, and females (A) and for nonovigerous and ovigerous females (B).
6.72 and $28.61 \mathrm{~mm}$ (see Figure 2B). There was a predominance of nonovigerous females in CL classes from 12.00 to $16.00 \mathrm{~mm}$ and ovigerous females in the higher classes (18-20 mm). Differences between size class distribution according to the ovigerous condition were statistically significant $(\mathrm{F}=259.13 ; \mathrm{p}<0.05)$.

The modal CL decreases along the depth range. The highest value occurred in the class $20-22 \mathrm{~mm}$ in the shallowest depths (101-150 m) and the lowest in the class 12-14 $\mathrm{mm}$ in the deepest depths (301-350 m) (as shown in Figure 3A). The differences in the mean CL between depth strata were statistically significant $(F=82.89$; $p<0.05)$.

Analysis of the length frequency by CL class and season showed that the highest and lowest ranges of sizes occurred in spring and winter, with 22.75 and $15.26 \mathrm{~mm}$, respectively (see Figure 3B).

Differences observed in mean CL by season were statistically significant $(F=215.83 ; p<0.05)$. GLM analysis allowed to conclude that the mean CL was related to depth, season, and sex $(F=30.89, p<0.05)$. Smaller males were found at deeper depth strata in autumn, winter and spring and at shallower depths in the summer. Larger females
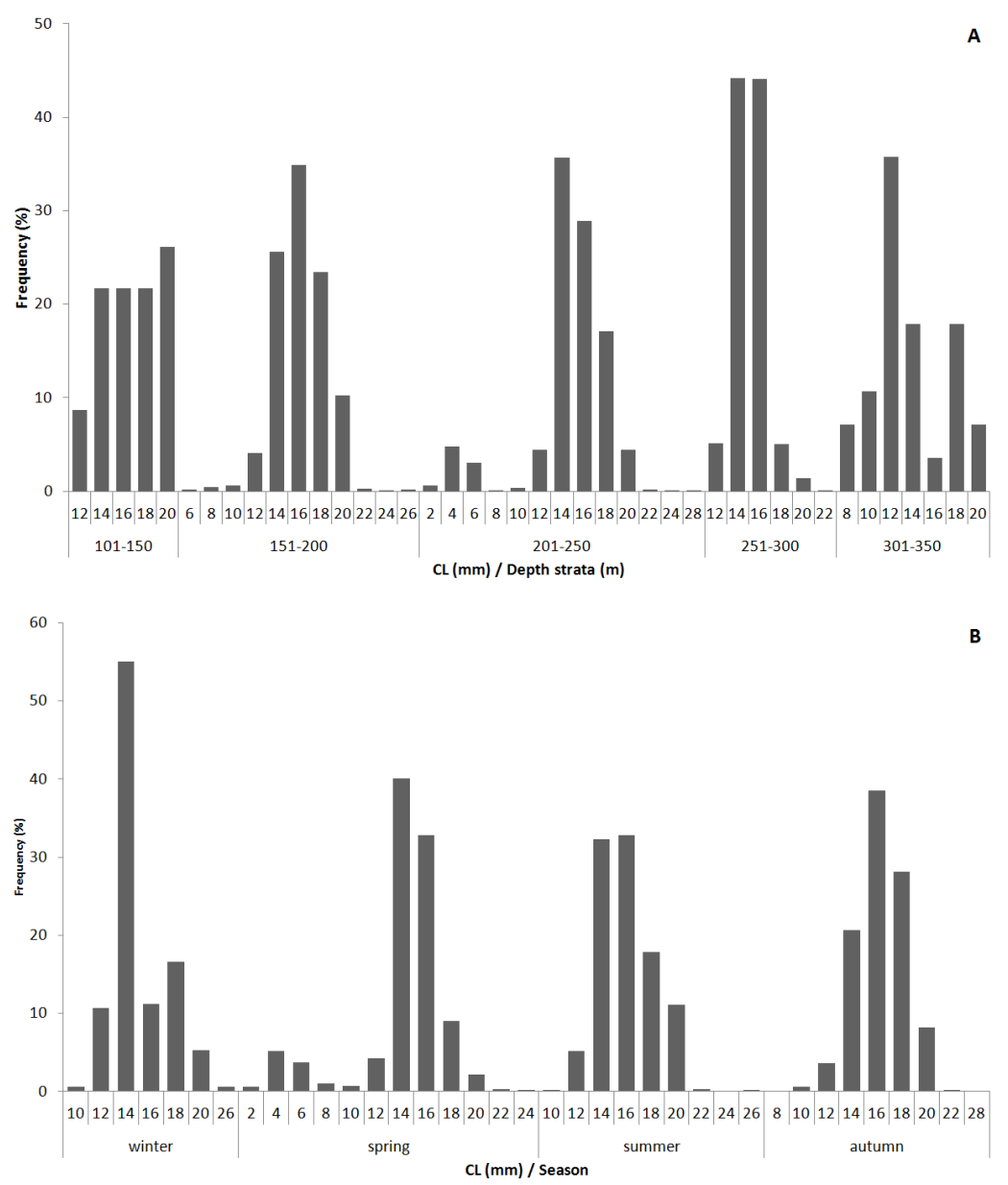

Figure 3. Size frequency of Plesionika narval caught in Madeira archipelago, Northeastern Atlantic, between 2004 and 2008 per CL class and depth stratum (A) and per CL class and season (B). 
were captured in deeper strata in winter and spring and in shallower strata in summer and autumn.

\subsection{Sex ratio and proportion of ovigerous females}

Sex ratio analysis showed that $57.70 \%$ of sampled specimens were males, $41.88 \%$ females and $0.42 \%$ was undetermined. The differences in sex ratio were statistically significant $\left(\chi^{2}=131.96 ; \mathrm{p}<0.05\right)$.

The relationship between sex ratio and depth showed that females predominated from 101 to $200 \mathrm{~m}$ and males from 201 to $350 \mathrm{~m}$ (see Figure 4A). $74.00 \%$ of the total females were distributed in the depth stratum [151-200]m while $54.00 \%$ of the males were distributed in the depth stratum [251-300] m. Differences in sex ratio between depth strata were not statistically significant $\left(\chi^{2}=7.43, p>0.05\right)$.

Females predominated in autumn with $72.94 \%$ and males in the other three seasons, with the highest incidence in the spring with $85.77 \%$ (as shown in Figure 4B). There were statistically significant differences in the sex ratio between seasons $\left(\chi^{2}=8.12 ; \mathrm{p}<0.05\right)$.

Females were more frequent at shallower depths in autumn and winter and dominated the deeper stratum (300-350 m) in spring. Males predominated at higher depths (251-300 m) in all seasons. Sex ratio per depth stratum did not depend on the season $\left(\chi^{2}=0.81 ; p>0.05\right)$.

In regard to ovigerous condition, $74.50 \%$ of the females were ovigerous and $25.50 \%$ were nonovigerous $\left(\chi^{2}=527.00, \mathrm{p}<0.05\right)$.

The proportion of females per depth stratum showed that ovigerous females predominated in all strata and reached a ratio of $100.00 \%$ in the 301 to $350 \mathrm{~m}$ stratum (see Figure 4C). The largest proportion of nonovigerous females occurred from 201 to $250 \mathrm{~m}$ (32.38\%). Differences were not statistically significant $\left(\chi^{2}=1.91, \mathrm{p}>0.05\right)$.

Ovigerous females predominated in all seasons with a higher incidence in summer, with $91.96 \%$ (as shown in Figure 4D). The season with the highest proportion of nonovigerous females was the winter with $38.71 \%$. Differences in the proportion of nonovigerous and ovigerous females by season were not statistically significant $\left(\chi^{2}=3.12, p>0.05\right)$.

Analysis of the proportion of females per season and depth shows that ovigerous females predominated in all seasons and depth strata. Even though the ovigerous condition does not appear to be solely dependent on season or depth $\left(\chi^{2}=0.003 ; \mathrm{p}>0.05\right)$, the observed seasonal and depth differences might indicate a possible trend of distribution of ovigerous females.

\section{Discussion}

\subsection{Abundance and distribution}

Plesionika narval has a wide bathymetric distribution, occurring in a range of depths from a few meters in the archipelago of Madeira (Biscoito, 1993), down to $910 \mathrm{~m}$ in the Red Sea (Chan and Crosnier, 1991). In the Macaronesian area the largest range of distribution of this species has been reported from the Azores, ranging between 18 and $864 \mathrm{~m}$ of depth (Martins and Hargreaves, 1991). The depth zonation of this species could be related to the environmental differences in the habitat along the depth range and might be in close relation to the exploitation of the available food by different sex and / or size groups as suggested by Thessalou-Legaki et al. (1989).

In the present study the specimens were captured between depths ranging from 101 to $350 \mathrm{~m}$. This depth
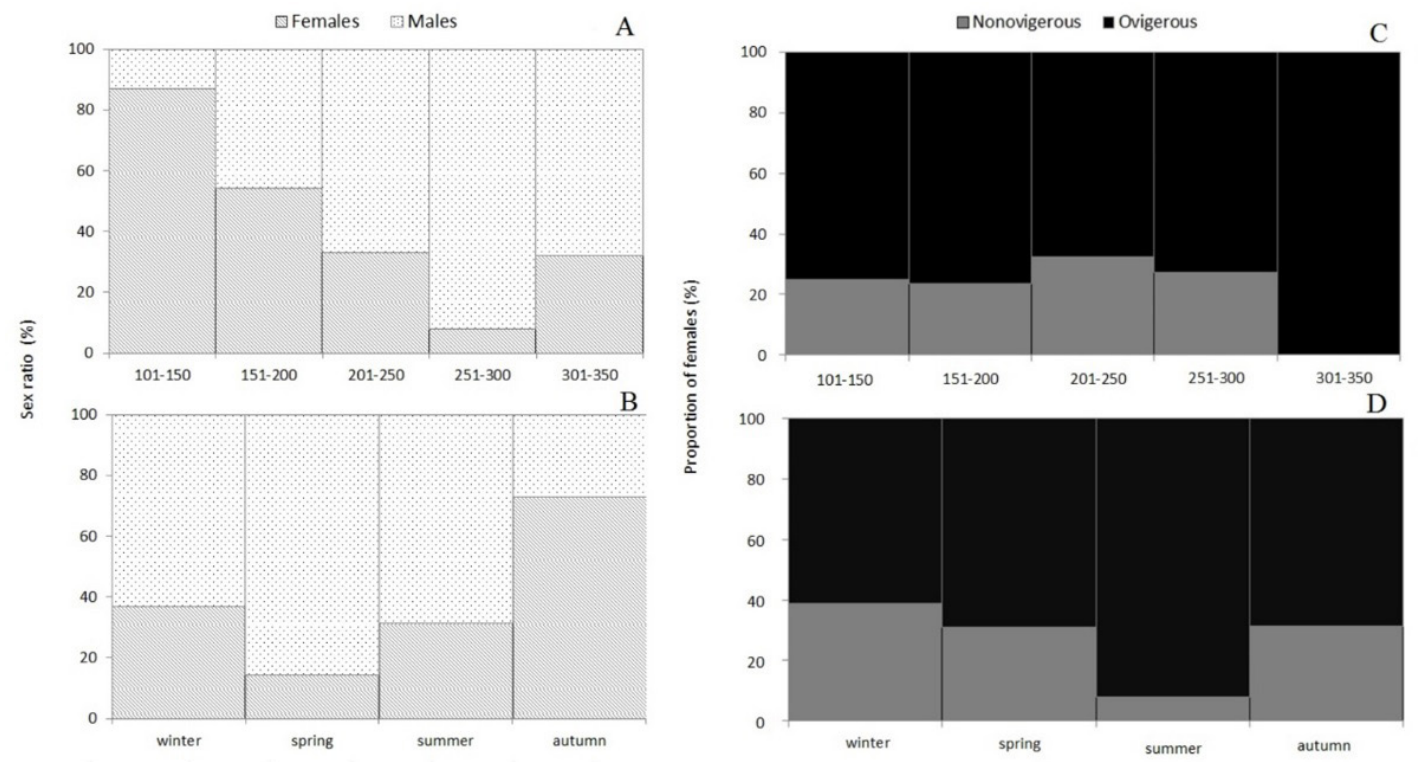

Figure 4. Sex ratio of Plesionika narval caught in Madeira archipelago, Northeastern Atlantic, between 2004 and 2008 by depth stratum (A) and season (B) and proportion of females according to ovigerous condition per depth stratum (C) and season (D). 
distribution fits $P$. narval occurrence intervals given for the archipelago of Madeira (Biscoito, 1993), Azores (Martins and Hargreaves, 1991), Canary Islands (González et al., 1997), Mediterranean (Carbonell and Abelló, 1998), Atlantic, Indo-Pacific Oriental (Chan and Crosnier, 1991) and Australia (Li and Davie, 2006).

The observed abundances ranged from 0.01 to 19.47 specimens per trap. A high variability was evidenced by our results, which might result from the distribution of $P$. narval along the slope or from the size of the mesh used in the traps as suggested for Plesionika edwardsii (Brandt, 1851) in the Mediterranean by Colloca (2002). Vertical migration behavior of this species (Thessalou-Legaki et al., 1989) could also have a significant effect on the fishing yield of fixed gear (Colloca, 2002), not allowing to identify significant differences in the abundance of this species along the depth range. Nonetheless, the highest mean abundances occurred between 151 and $200 \mathrm{~m}$ of depth suggesting a possible similar abundance trend as that described in the Azores (Martins and Hargreaves, 1991) and the Canaries (González et al., 1997), in which the highest mean abundances occurred up to $175 \mathrm{~m}$ of depth. P. narval seems to inhabit preferably shallow waters in the Macaronesian archipelagos (González et al., 1997), contrary to what occurs in the Mediterranean (Holthuis, 1987) and in north-west Africa (Crosnier and Forest, 1973; Lagardère, 1981) where this species is captured preferably between 200 and $500 \mathrm{~m}$ of depth.

Abundances of $P$. narval were found to vary between seasons, which may be explained by the population dynamics of the species, especially in terms of recruitment. The incoming recruits in the adult population in the spring may result in the increased abundance found in summer, when specimens reach sizes that are vulnerable to fishing traps (Sousa et al., 2014).

The distribution pattern of abundance of $P$. narval in Madeira varies throughout the year, as occurs in the Canary Islands (González et al., 1997). The pattern obtained suggests that this species undertakes seasonal vertical migrations in the Northeastern Atlantic, as previously observed in
Mediterranean waters by Thessalou-Legaki et al. (1989). Seasonal fluctuations observed in the abundance of this species between the Macaronesian archipelagos may result from differences in water temperature and productivity across regions.

\subsection{Size composition}

The size range of sampled specimens in this study varied between 2.45 and $28.61 \mathrm{~mm}$ and is in agreement with that reported by González et al. (1997) for the Canary archipelago and Martins and Hargreaves (1991) for the Azores. A comparison of size amplitudes between different geographic areas (see Table 2) shows that the specimens sampled in the Northeastern and Eastern Central Atlantic, particularly in the Macaronesian archipelagos of Madeira, Azores and Canaries feature greater sizes than those caught in the Mediterranean, Indian and Pacific. Larger sizes observed in these areas may be justified by the oligotrophic nature of waters. As it is believed that in less productive waters specimens grow at slower rates and reach larger sizes (Hartnoll, 1983).

Our study indicated that larger specimens of $P$. narval were more predominant in Madeira archipelago compared to specimen size reported by González et al. (1997) for the Canary Islands. The difference obtained in CL distribution between archipelagos may be due to the greater availability of food, the highest water temperature and larger continental slope in the Canary Islands (Arístegui et al., 2006).

P. narval presented a CL distribution pattern per sex characterized by the predominance of males in the lower classes and females in the higher, showing that females had a mean size significantly higher than males. The same pattern was described for this species in Canary Islands (Lozano et al., 1990; González et al., 1997) and for other pandalid species such Plesionika heterocarpus (A. Costa, 1871) (Company and Sardà, 2000), Plesionika martia (A. Milne-Edwards, 1883) (Company and Sardà, 2000; Maiorano et al., 2002), P. edwardsii, Plesionika gigliolli (Senna, 1902) and Plesionika acanthonotus (Smith, 1882) (Company and Sardà, 2000) in Mediterranean and

Table 2. Carapace length (CL) range of Plesionika narval from different geographical areas.

\begin{tabular}{crc}
\hline Geographical area & & CL range (mm) \\
\hline Madeira archipelago & $2.45-28.61$ & Present study \\
Azores archipelago & $8.00-27.00$ & (Martins and Hargreaves, 1991) \\
Canary Islands & $2.00-30.00$ & (González et al., 1997) \\
Rhodos Island (Greece) & $7.00-19.00$ & (Thessalou-Legaki et al., 1989) \\
Mediterranean Sea & $11.00-19.00$ & (Chan and Crosnier, 1991) \\
Eastern Atlantic & $14.50-17.50$ & (Chan and Crosnier, 1991) \\
Reunion Island & $12.00-18.50$ & (Chan and Crosnier, 1991) \\
Madagascar & $11.50-13.50$ & (Chan and Crosnier, 1991) \\
Seychelles & $10.50-13.00$ & (Chan and Crosnier, 1991) \\
Taiwan & $11.50-22.50$ & (Chan and Crosnier, 1991) \\
South Pacific (New Caledonia / Tahiti) & $8.00-14.00$ & (Chan and Crosnier, 1991) \\
Philippines, Indonesia & $12.00-20.00$ & (Chan and Crosnier, 1991)
\end{tabular}

CL, carapace length. 
P. edwardsii (Lozano et al., 1990) and Heterocarpus ensifer A. Milne-Edwards, 1881 (Tuset et al., 2009) in the Canary Islands. These gender differences may be related to morphological development of each sex, with the differential investment in reproduction between the sexes and the energy available in the habitat where they are distributed (King, 1995).

The ovigerous females range between 6.72 and $28.61 \mathrm{~mm}$. It was recorded the smallest ovigerous female ever reported for this species. The smallest size obtained was lower than that reported for the Canary Islands $(8.00 \mathrm{~mm})$ and the Azores (12.00 mm) (Martins and Hargreaves, 1991; González et al., 1997). The comparison between the size composition of nonovigerous and ovigerous females showed that nonovigerous have smaller mean sizes than ovigerous females. This pattern was also determined in the Azores (Martins and Hargreaves, 1991) and Canary Islands (González et al., 1997). Comparison of CL between Madeira, the Canaries and the Azores, by sex and ovigerous condition shows that the mean sizes are higher in Madeira, for all groups, contrary to the Azores presenting the smaller sizes.

Changes in the population structure with depth have been reported for several species of pandalids, mainly for Pandalus borealis Krøyer, 1838 that showed clear stratification of size according to depth, with occurrence of larger individuals in deeper waters (Frechette and Parsons, 1981). Similar pattern was reported for P. edwardsii (Carbonell and Abelló, 1998), P. martia, P. heterocarpus (Vafidis et al., 2008) and Heterocarpus sibogae de Man, 1917 (King and Butler, 1985) and opposite for H. ensifer and Heterocarpus laevigatus Spence Bate, 1888 (Gooding, 1984), which showed a decrease in size as the depth increases.

Studies with P. narval in the Canary Islands (González et al., 1997) and the Mediterranean (Thessalou-Legaki et al., 1989) showed a similar pattern of size increasing as the depth increases. For the specimens sampled in the Canary Islands the pattern was similar for both sexes and coincident for females in the Mediterranean, since the males had similar sizes at all depths sampled. In the present study, when considering depth independently, variations in size resulted in a decrease of CL with increasing depth, but when considered both depth and season, we found a pattern identical to that reported by Thessalou-Legaki et al. (1989) and González et al. (1997) for spring and similar to that described by Gooding (1984) for H. ensifer and H. laevigatus, for other seasons.

Migration of shrimps to deeper waters is cited as the main cause of the existence of these size distribution patterns concerning depth (Allen, 1966). These may be related to the need to reduce intraspecific competition for space and food along the CL classes (Cartes, 1993). Larger specimens migrate to deeper waters as they present greater capacity in food acquisition in habitats where it is scarce (Mauchline, 1972). The highest mean sizes were observed in autumn contrary to spring with lower mean sizes, probably due to higher CL amplitudes observed in this season. This could be explained by the introduction of new recruits in the adult population, which in Madeira occurs mainly in spring and may act as a stimulus to the migration of larger specimens to deeper waters, thus avoiding intra-specific competition for space and food (Sousa et al., 2014).

\subsection{Sex ratio and proportion of ovigerous females}

P. narval showed a trend in bathymetric distribution according to sex. Males were more abundant in the deeper strata and females at shallower depths, the reversal in sex ratio was found to occur around a depth of $201 \mathrm{~m}$. The observed pattern is consistent with that reported for the Canary archipelago (Lozano et al., 1990) and Eastern Mediterranean (Thessalou-Legaki et al., 1989). This trend may result from habitat differences over the bathymetric strata and the use of different food resources available for different sexes and / or sizes of groups, as suggested by Thessalou-Legaki et al. (1989).

Females generally predominate in the larger CL classes, but between 101 and $200 \mathrm{~m}$ of depth these dominate almost all classes. This female dominance in all class lengths in shallower waters could be related to the nesting depth of this species, since all females with CL exceeding $7.00 \mathrm{~mm}$ may be involved in reproduction (Sousa et al., 2014). Distribution of females per depth strata is in agreement with that reported by González et al. (1997) for the Canary Islands.

Regarding seasonality, $P$. narval showed a pattern in sex ratio throughout the year, with a predominance of males in winter, spring and summer and females in autumn. In spring the females predominated in the deeper strata unlike in the other seasons when a more evident predominance of females at shallower waters occurred as observed in autumn, consolidating the hypothesis of seasonal migrations related to the reproductive cycle of the species.

The proportion of ovigerous females was higher than the nonovigerous (3:1), with preponderance of the same in all depth strata and seasons.

Ovigerous females have the maximum occurrence (76.88\%) on shallower depths between 101 and $200 \mathrm{~m}$, which is in agreement with the pattern obtained for the Canary Islands by González et al. (1997), who reported the existence of $77.20 \%$ between 51 and 175 and in disagreement with the inverse pattern for this species found in the Mediterranean by Thessalou-Legaki (1992). The difference between the distribution patterns of ovigerous females throughout the depth gradient, suggests that the spawning season in the Eastern Central Atlantic occurs at shallower depths and at greater depths in the Mediterranean. The difference in spatial distribution between these regions may be explained by environmental specificity of the hydrodynamic conditions, dynamic topography and increments of different productivity.

Ovigerous females showed a trend of seasonal migration with depth in the archipelago of Madeira. These trends are common in pandalids and were reported to the Canaries (González et al., 1997) and Mediterranean (Thessalou-Legaki, 1992) for this species and for P. martia (Maiorano et al., 
2002) and P. edwardsii (García-Rodríguez et al., 2000) in the Mediterranean.

In the archipelago of Madeira, ovigerous females remain in shallower water in winter, summer and autumn and migrate to deeper waters in spring. Autumn had the highest frequency of ovigerous females between 101 and $200 \mathrm{~m}$, confirming the hypothesis that spawning of this species occurs in shallow waters, especially during this season. Ovigerous females showed a strong migratory movement from deeper water in spring to shallower depths in the summer after which begins the spawning season in autumn, the ovigerous females remain in shallow water for the duration of the spawning season and begin descent to deeper waters as winter approaches. The migratory pattern observed by González et al. (1997) for this species in the Canary Islands, showed that ovigerous females move to deeper waters in autumn and remain in shallow waters in the other seasons. The difference in the distribution of ovigerous females, between Madeira and Canary Islands according to depth in different seasons, suggests that the main spawning season in Madeira is late, probably due to biotic and abiotic differences observed between these two regions. Nevertheless, $P$. narval has a continuous breeding period in the archipelago of Madeira, with the occurrence of ovigerous females throughout the year.

\section{Conclusions}

Our study on the deep-water shrimp P. narval revealed a model of population dynamics, similar to other pandalid shrimps, in which there is size stratification in relation to depth, with larger individuals concentrated in deeper waters, there are also differences in carapace length between sexes with females attaining larger sizes as a result of differences in growth, mortality, migration and habitat preference, and seasonal vertical migrations related with reproduction and/or feeding behavior. In addition, the observation of ovigerous females all year round shows the existence of a continuous breeding period with a peak in the summer.

\section{Acknowledgements}

The authors are grateful to the Fisheries Research Service (DSI) from the Regional Directorate of Fisheries of the Autonomous Region of Madeira for providing the data used in this study. We are also thankful to Francisco Fernandes, Tomás Chada, Viriato Timóteo and technicians of DSI for their help in the course of this work, namely in biological sampling and fishing surveys. Acknowledgments are also due to the crew of the fishing vessel Baía de Câmara de Lobos. Financial support was granted by the UE FEDER in the framework of the Project MARISCOMAC - MAC/2.3d/097 and the Regional Government of Madeira. The first author (RS) was supported by a Grant from ARDITI-OOM/2016/010 (M1420-01-0145-FEDER-000001-Observatório Oceânico da Madeira-OOM).

\section{References}

ALLEN, J.A., 1966. The rhythms and population dynamics of decapod Crustacea. Oceanography and Marine Biology: An Annual Review, vol. 4, pp. 247-265.

ARCULEO, M., MAZZOLA, A. and RIGGIO, S., 2002. Catture sperimentali con le nasse di Plesionika narval (Fabr.) (Crustacea Decapoda) nell'isola di Ustica (Tirreno Meridionale). Naturalista Siciliano, vol. 2, no. 1, pp. 13-20.

ARÍSTEGUI, J., ÁLVAREZ-SALGADO, X.A., BARTON, E.D., FIGUEIRAS, F.G., HERNÁNDEZ-LEÓN, S., ROY, C. and SANTOS, A.M.P., 2006. Oceanography and fisheries of the Canary current/iberian region of the Eastern North Atlantic. In: A.R. ROBINSON and K.H. BRINK, eds. The sea. Cambridge: Harvard University Press, pp. 879-934. The Global Coastal Ocean: Interdisciplinary Regional Studies and Syntheses, no. 14.

BISCOITO, M.J., 1993. An account of the shrimps of the family Pandalidae (Crustacea, Decapoda, Caridea) in Madeiran waters. Courier Forschungsinstitut Senckenberg, vol. 159, pp. 321-325.

CARBONELL, A. and ABELlÓ, P., 1998. Distribution characteristics of pandalid shrimps (Decapoda: Caridea: Pandalidae) along the western Mediterranean Sea. Journal of Natural History, vol. 32, no. 10-11, pp. 1463-1474. http://dx.doi. org/10.1080/00222939800771001.

CARTES, J.E., 1993. Diets of deep-water pandalid shrimps on the western Mediterranean slope. Marine Ecology Progress Series, vol. 96, pp. 49-61. http://dx.doi.org/10.3354/meps096049.

CARTES, J.E., ABELLÓ, P., LLORIS, D., CARBONELL, A., TORRES, P., MAYNOU, F. and GIL DE SOLA, L., 2002. Feeding guilds of western Mediterranean demersal fish and crustaceans: an analysis based on a spring survey. Scientia Marina, vol. 66, no. 2, pp. 209-220. http://dx.doi.org/10.3989/scimar.2002.66s2209.

CARTES, J.E., SARDÀ, F. and ABELLÓ, P., 1993. Decapod crustaceans collected by deep-water trawls (between 1000 and $2200 \mathrm{~m}$ ) in the Catalan area (North-Western Mediterranean). Bios, vol. 1, pp. 207-213

CHAN, T. and CROSNIER, A., 1991. Crustacea Decapoda: studies of the Plesionika narval (Fabricius, 1787) group (Pandalidae) with description of six new species. In: A. CROSNIER, ed. Resultats des Campagnes Musorstom. Paris: Mémoires du Muséum National d'Históire Naturelle, vol. 9, pp. 413-461.

COLLOCA, F., 2002. Life cycle of the deep-water pandalid shrimp Plesionika edwardsii (Decapoda, Caridea) in the Central Mediterranean Sea. Journal of Crustacean Biology, vol. 22, no. 4, pp. 775-783. http://dx.doi.org/10.1163/20021975-99990291

COMPANY, J.B. and SARDÀ, F., 2000. Growth parameters of deep-water decapod crustaceans in the northwestern Mediterranean Sea: a comparative approach. Marine Biology, vol. 136, no. 1, pp. 79-90. http://dx.doi.org/10.1007/s002270050011.

CRAWLEY, M., 2002. Statistical computing: an introduction to data analysis using S-plus. London: John Wiley \& Sons Inc., 772 p.

CROSNIER, A. and FOREST, J., 1973. Les crevettes profondes de l'Atlantique Oriental tropical. Faune Tropicale, vol. 19, pp. 1-409.

FRECHETTE, J. and PARSONS, D.J., 1981. Report of shrimp ageing workshop held at Ste. Foy, Quebec, in May and at Dartmouth, Nova Scotia, in November 1981. NAFO Scientific Council Studies, vol. 6, pp. 79-100. 
GARCÍA-RODRIGUEZ, M., ESTEBAN, A. and PEREZ GIL, J.L., 2000. Consideration on the biology of Plesionika edwardsii (Brandt, 1851) (Decapoda, Caridea, Pandalidae) from experimental trap catches in the Spanish western Mediterranean Sea. Scientia Marina, vol. 64, no. 4, pp. 369-379. http://dx.doi.org/10.3989/ scimar.2000.64n 4369 .

GONZÁLEZ, J.A., TUSET, V.M., LOZANO, I.J. and SANTANA, J.I., 1997. Biology of Plesionika narval (Crustacea, Decapoda, Pandalidae) around the Canary Islands (Eastern Central Atlantic). Estuarine, Coastal and Shelf Science, vol. 44, no. 3, pp. 339-350. http://dx.doi.org/10.1006/ecss.1996.0122.

GOODING, R.M., 1984. Trapping survey for the deepwater caridean shrimps, Heterocarpus leavigatus and H. ensifer in the north-western Hawaiian Islands. Marine Fisheries Review, vol. 46, no. 2, pp. 18-26.

HARTNOLL, R.G., 1983. Growth. In: D.E. BLISS, ed. The biology of Crustacea. New York: Academic Press, vol. 8, pp. 214-282.

HOLTHUIS, L.B., 1980. FAO species catalogue: shrimps and prawns of the world: an annotated catalogue of species of interest to fisheries. FAO Fisheries Circular, vol. 125, no. 1, pp. 1-271.

HOLTHUIS, L.B., 1987. Crevettes. In: W. FISCHER, M. SCHNEIDER and M.L. BAUCHOT, eds. Fiches FAO d'identification des espèces pour les besoins de la pêche: Méditerranée et Mer Noire: zone de pêche 37 (revision 1), 1, végétaux et invertébrés. Rome: Food and Agriculture Organization of the United Nations. pp. 189-292.

INTERNATIONAL BUSINESS MACHINES CORPORATION - IBM, 2011. IBM SPSS Statistics for Windows, Version 20.0. New York: IBM Corp.

KING, M., 1995. Fisheries biology assessment and management. Oxford: Fishing News Books, 342 p.

KING, M.G. and BUTLER, A.J., 1985. Relationship of life-history patterns to depth in deep-water caridean shrimps (Crustacea: Natantia). Marine Biology, vol. 86, no. 2, pp. 129-203. http:// dx.doi.org/10.1007/BF00399018.

LAGARDÈRE, J.P., 1981. Shrimps and prawns. In: W. FISCHER, G. BIANCHI and W.B. SCOTT, eds. Fiches FAO species identification sheets for fishery purposes: Eastern Central Atlantic: fishing areas 34, 47 (in part). Ottawa: Food and Agriculture Organization of the United Nations, vol. 6, pp. 1-304.

LI, X. and DAVIE, P.J.F., 2006. An account of the pandaloid shrimps (Crustacea: Decapoda: Caridea) in the collections of the Quensland Museum. Memoirs of the Queensland Museum, vol. 52, no. 1, pp. 151-170.

LI, X., 2006. Additional pandaloid shrimps from the South China Sea (Crustacea: Decapoda: Caridea), with description of one new species. The Raffles Bulletin of Zoology, vol. 54, no. 2, pp. 361-372.

LOZANO, G., CARRILLO, J., CALDENTEY, M., SANTANA, J., LOZANO, I., GONZÁLEZ, J., JIMENÉZ, S., LOZANO, F., BRITO, A., FANLO, M. and HERNÁNDEZ, C., 1990. Distribución estacional y batimétrica de Pandálidos en el talud de Gran Canaria. In: L. GALLEGO-CASTEJON, ed. Bentos VI. Palma de Maiorca: Edit. Bilbilis, pp. 213-221.
MAIORANO, P., D'ONGHIA, G., CAPEZZUTO, F. and SION, L., 2002. Life-history traits of Plesionika martia (Milne Edwards, 1883) (Decapoda: Caridea) from the eastern-central Mediterranean Sea. Marine Biology, vol. 141, no. 3, pp. 527-539. http://dx.doi. org/10.1007/s00227-002-0851-4.

MARTINS, H. and HARGREAVES, P., 1991. Shrimps of the Families Pandalidae and Hippolytidae (Crustacea: Decapoda) caught in benthic traps off the Azores. Arquipélago Life and Marine Sciences, vol. 9, pp. 47-61.

MAUCHLINE, J., 1972. The biology of bathypelagic organisms, especially Crustacea. Deep-Sea Research, vol. 19, pp. 753-780. http://dx.doi.org/10.1016/0011-7471(72)90097-6.

SOUSA, R., HENRIQUES, P., BISCOITO, M., PINTO, A.R., DELGADO, J., DELLINGER, T., GOUVEIA, L. and PINHO, M.R., 2014. Considerations on the Biology of Plesionika narval (Fabricius, 1787) in the Northeastern Atlantic. Turkish Journal of Fisheries and Aquatic Sciences, vol. 14, pp. 727-737. http:// dx.doi.org/10.4194/1303-2712-v14_3_15.

SOUSA, R., PINHO, M.R., DELGADO, J., BISCOITO, M., PINTO, A.R., DELLINGER, T., GOUVEIA, L., CARVALHO, D. and HENRIQUES, P., 2017. Prospective study of the fishery of the shrimp Plesionika narval (Fabricius, 1787) in the Northeastern Atlantic. Brazilian Journal of Biology $=$ Revista Brasileira de Biologia, vol. 77, no. 3, pp. 1-9. PMid:27783766.

THESSALOU-LEGAKI, M., 1989. Allometric growth of male secondary sexual characters and dioecy in Parapandalus narval (Decapoda: Pandalidae). Journal of Crustacean Biology, vol. 9, no. 4, pp. 595-600. http://dx.doi.org/10.2307/1548591.

THESSALOU-LEGAKI, M., 1992. Reproductive variability of Parapandalus narval (Crustacea: Decapoda) along a depth gradient. Estuarine, Coastal and Shelf Science, vol. 35, no. 6, pp. 593-603. http://dx.doi.org/10.1016/S0272-7714(05)80041-1.

THESSALOU-LEGAKI, M., FRANTZIS, A., NASSIOKAS, K. and HATZINIKOLAOU, S., 1989. Depth zonation in a Parapandalus narval (Crustacea, Decapoda, Pandalidae) population from Rhodos Island, Greece. Estuarine, Coastal and Shelf Science, vol. 29, no. 3, pp. 273-284. http://dx.doi.org/10.1016/0272-7714(89)90058-9.

TUSET, V.M., PÉREZ-PENÃLVO, J.A., DELGADO, J., PINHO, M.R., SANTANA, J.I., BISCOITO, M., GONZÁLEZ, J.A. and CARVALHO, D., 2009. Biology of the deep-water shrimp Heterocarpus ensifer (Caridea: Pandalidae) off the Canary, Madeira and the Azores Islands (Northeastern Atlantic). Journal of Crustacean Biology, vol. 29, no. 4, pp. 507-515. http://dx.doi. org/10.1651/08-3070.1.

VAFIDIS, D., LEONTARAKIS, P.K., DAILIANIS, T. and KALLIANIOTIS, A., 2008. Population characteristics of four deepwater pandalid shrimps (Decapoda: Caridea) in the northern Aegean Sea (NE Mediterranean). Journal of Natural History, vol. 42, no. 31, pp. 2079-2093. http://dx.doi.org/10.1080/00222930802254672.

ZAR, J.H., 1996. Biostatistical analysis. New Jersey: PrenticeHall, $662 \mathrm{p}$.

ZARIQUIEY-ALVAREZ, R., 1968. Crustáceos Decápodos Ibéricos. Investigaciones Pesqueras, vol. 32, pp. 1-510. 